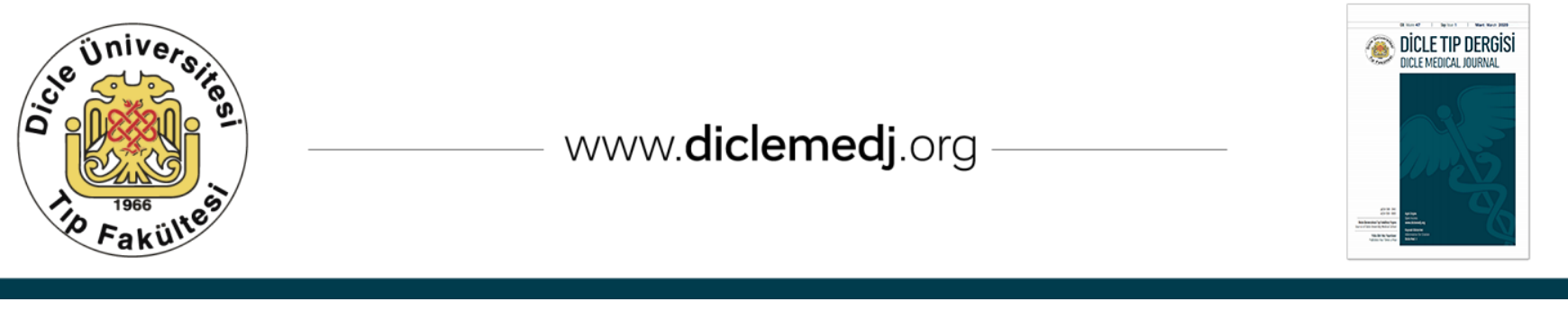

Özgün Araștırma / Original Article

\title{
Bir Diyabet Kampı: Öncesi ve Sonrası?
}

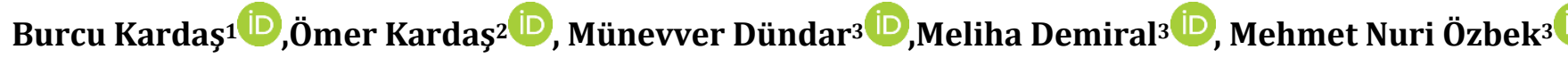 \\ 1 Diyarbakır SBÜ Gazi Yaşargil Eğitim ve Araştırma Hastanesi, Çocuk ve Ergen Psikiyatri Kliniği, Diyarbakır, Türkiye \\ 2 Dicle Üniversitesi Tıp Fakültesi, Çocuk ve Ergen Psikiyatri Kliniği, Diyarbakır, Türkiye \\ 3 Diyarbakır SBÜ Gazi Yaşargil Eğitim ve Araştırma Hastanesi, Pediatrik Endokrinoloji Kliniği, Diyarbakır, Türkiye
}

Geliş: 13.08.2019; Revizyon: 16.01.2020; Kabul Tarihi: 21.01.2020

$\ddot{0} \mathbf{z}$

Giriş: Çalışmamızın amacı, pediatrik endokrinoloji kliniğinde takip edilen Tip 1 diabetes mellitus (DM) tanılı çocuk ve ergenlerde, diyabet kampının; HbA1c, vücut kitle indeksi (VKİ) ölçümlerine, anksiyete ve depresyon puanlarına ve yaşam kalitesi değişimlerine etkisini incelemektir. Olgular kampa gitmeden ve kampa katıldıktan 6 ay sonra değerlendirilmiştir.

Yöntemler: Çalışmamızda 2018 yılında, 29 Temmuz-7 Ağustos tarihleri arasında İznik'te gerçekleştirilen kampta, Diyarbakır'dan katılan olgular değerlendirilmiştir. Arkadaşım Diyabet Kampı'na katılan 17 olgunun HbA1c düzeyleri, VKİ, çocuklar için depresyon ölçeği (ÇDÖ), Çocuklarda Anksiyete Tarama Ölçeği (ÇATÖ) ve Yaşam Kalitesi Ölçeği (çocuklar ve ergenler için) puanları kampa katılmadan önce ve kampa katıldıktan 6 ay sonra değerlendirilmiştir.

Bulgular: Çalışmaya alınan 17 olgu pediatrik endokrinoloji kliniğinde takipli 720 hastanın arasında daha önce kampa katılmamış ve ailesi kampa katılmasını kabul eden tip 1 DM'li olgulardan seçilmiştir. Grubun yaş ortalaması 13,1(min:10maks:17,5),tanı alma yaşı ortalaması 7,6 (min:1-maks:15) olarak saptanmıştır. HbA1c düzeyleri, VKİ ve ölçek puanları değerlendirildiğinde kamp öncesi ve sonrası anlamlı fark bulunamamıştır. Ancak 6. ayda ölçülen HbA1c düzeyleri ile depresyon ve anksiyete puanları ile pozitif, yaşam kalitesi puanları ile negatif yönde bir ilişki bulunmuştur. Bu ilişkinin anlamlı olduğu saptanmıștır $(\mathrm{p}<0.05)$.

Sonuç: Diyabet kampları diyabete yönelik eğitimlerin yapıldığı, akran desteğinin olduğu, hem bilgilendirici hem eğlendirici ortamlardır. Bizim çalışmamız kamp etkinliğinin depresyon, anksiyete ve yașam kalitesi üzerine kısa dönemde (6 ay) olumlu bir etkisi olmadığını ortaya koymuștur. Ancak psikiyatrik etkilerini değerlendirmek için uzun izlemli çalışmalara ihtiyaç vardır.

Anahtar kelimeler: tip 1 DM, çocuk, adölesan, kamp

DOI: 10.5798/dicletip.706124

Yazışma Adresi / Correspondence: Burcu Kardaș, Diyarbakır SBÜ Gazi Yaşargil Eğitim ve Araştırma Hastanesi, Çocuk ve Ergen Psikiyatri Kliniği e-

mail: burcu-atar@hotmail.com 


\title{
A diabetes Camp: Before and After?
}

\begin{abstract}
Objective: The aim of our study was to investigate the effects of diabetes camp on HbA1c, Body Mass Index (BMI) measurements, anxiety and depression scores and quality of life changes in children and adolescents with type 1 diabetes mellitus (DM) followed up in our pediatric endocrinology clinic.

Method: We included the participants from the diabetes camp between 29 July-7 August 2018 in İznik coming from Diyarbakır. We evaluated HbA1c levels, BMI, Children for depression Scale (CDI), Childhood Anxiety Disorders SelfReport Scale (SCARED) and Quality Of Life for Children and Adolescent Scale scores of 17 cases who participated in "My Friend Diabetes" camp.

Results: Seventeen cases with type $1 \mathrm{DM}$ were recruited to the study among 720 patients of the pediatric endocrinology outpatient clinic who never attended the camp before and whose parents were volunteering their children to join the camp. The mean age of the group was 13.1 (min: 10-max: 17.5) and the mean age of receiving diagnosis was 7.6 (min: 1 max: 15). When HbA1c levels, BMI and scale scores were evaluated, no significant difference was found before and after the camp. However, after 6 months, there were positive correlations between HbA1c levels, and depression and anxiety scores, but a negative correlation between HbA1c levels and quality of life scores. These correlations were found to be significant $(\mathrm{p}<0,05)$.

Conclusion: The diabetes camps are both informative and entertaining activities where diabetes-focused education and peer supports are provided. Our study demonstrated that camp activity had no significant positive effects on depression, anxiety, and quality of life in the short term (6 months). However, long-term studies are needed to evaluate accurate psychiatric effects.
\end{abstract}

Keywords: type 1 DM, child, adolescent, camp.

\section{GíRIŞ}

Tip 1 Diabetes Mellitus (DM) immun sistem aracılı olduğu düşünülen genellikle çocukluk ve ergenlik çağında ortaya çıkan, ömür boyu tedavi gerektiren bir hastalıktır. Çocukluk ve ergenlik çağında en sık görülen kronik hastalıkların başında gelir1. İnsidansı ve prevelansı ülkelere göre değişiklik göstermektedir. Dünya'da 180 milyon tip 1 DM tanılı çocuk ve ergen olduğu tahmin edilmektedir ${ }^{2}$. 1920'de insülinin keşfi ile bu hastalığın tedavisi mümkün kılınmış, bu hastaların erişkin yaşa gelmeleri sağlanmıştır. $\mathrm{Bu}$ kronik durumla uzun süre baş etmek zorunda kalan çocuk ve gençleri psikososyal ihtiyaçlarını karşılamak için kamp gibi ortamlar oluşturulmaya başlanmıştır. Her yıl dünya genelinde 46000 çocuk ve ergenin bu kamplara katıldığı bildirilmektedir. Kamplar hem tıbbi yardımların (kan şekerini ölçme ve değerlendirme, insülin enjeksiyonlarının yapılması vb.) yapıldığı, hem de tip 1 DM tanılı olguların bir araya gelip sosyal ihtiyaçlarını karşılayabildiği bir yer olmuştur. Bu kamplar diyabetli olguların daha az yalıtılmış hissettiği, diyabetin nasıl yönetileceğinin öğretildiği, hem eğitim hem eğlence alanlarının olduğu ortamlar olarak bildirilmektedir ${ }^{3}$. Illk olarak 1925 yılında Amerika'da tip 1 DM tanılı çocuklar için düzenlenen kamp, ülkemizde 1997 yllından itibaren düzenli olarak yapılmaktadır ${ }^{4,5}$. Genel olarak diyabet yönetimini kendisi yapabilen çocukların dahil edildiği kamplar karbohidrat sayımı, acil durumların yönetimi, diyabet ile ilişkili komplikasyonlar, insülin pompası kullanımı, yeni tedavi yöntemleri, stres yönetimi ve başetme becerileri gibi konulardan oluşturulan bir eğitim programına sahiptir. Kampa alınan olgular bireysel ya da aileler ile alınabilmektedir. Kamplar genelde üç gün ile 1 hafta kadar sürmektedir ${ }^{4}$. 
Tip 1 DM tanılı olgular normal popülasyona göre psikiyatrik hastalıklar açısından risk altındadırlar. Özellikle adölesan dönemde depresif bozukluklar, anksiyete bozukluğu, yeme ve davranış bozuklukları belirtileri gösterebilirler6. Adölesan dönem fiziksel, hormonal değişimlerin yanısıra ruhsal değișimlerin de yoğun olarak yaşandığı çalkantılı bir dönemdir. Dönemsel zorluklar yanında kronik hastalıklarla da başetmek zorunda kalan adölesanlar ruhsal bozukluklar ile karşı karşıya gelebilirler. Yapılan çalışmalarda tip 1 DM'li olgularda olmayanlara göre 2-3 kat daha fazla psikiyatrik bozukluğa rastlandığ $\quad$ bildirilmiştir ${ }^{7}$ Psikiyatrik hastalıkların diyabet tanılı olgularda, ciddi hipoglisemi ve hiperglisemi, kilo alımı, mikrovasküler bozukluklar gibi kısa ve uzun dönem komplikasyonları artırdığı bilinmektedir ${ }^{8}$. Ayrıca zayıf glisemik kontrol ile psikiyatrik hastalıklar arasında pozitif bir ilişki saptanmıştır9.

Kronik hastalıklar bireylerin yaşam kalitesini etkileyen en önemli durumlardandır. Kișinin ve ailesinin yaşam tarzının kökten değiștirir. Tip 1 DM tanılı olguların genel popülasyon ile karşılaştırıldıklarında sağlıkla ilgili yaşam kalitelerinin daha düşük olduğu bilinmektedir ${ }^{10}$. Tip 1 DM'li çocuk ve ergenlerde; daha iyi glisemik kontrol, daha iyi büyüme ve gelişme ve daha az komplikasyon daha yüksek yaşam kalitesi ile ilişkili bulunmuştur ${ }^{11}$.

Çalışmamızın amacı Tip 1 DM tanılı çocuk ve ergenlerde diyabet kampının; HbA1c, vücut kitle indeksi (VKİ) ölçümlerine, anksiyete ve depresyon puanlarına ve yaşam kalitesi değişimlerine etkisini değerlendirmektir. Çalışmamız bu alanda ülkemizde yapılan çalışmalar olmasına rağmen HbA1c ve VKİ ile beraber depresyon, anksiyete, yaşam kalitesini değerlendiren ilk çalışma olma özelliğini taşımaktadır.

\section{YÖNTEMLER}

\section{Katılımcılar}

Çalışmaya Sağlık Bilimleri Üniversitesi (SBÜ) Diyarbakır Gazi Yaşargil Eğitim ve Araştırma Hastanesi Pediatrik Endokrinoloji Kliniği'nde takipli hastalar dahil edilmiștir. Olgular pediatrik endokrinoloji kliniğinde takipli Tip 1 DM tanılı 720 hasta arasından daha önce kampa katılmamış ve ailesi kampa katılmasına izin veren bireylerden seçilmiştir. Diyabet Kampı katılımı öncesi olgulardan ve ailelerinden yazılı onam alınmıştır. $11 \mathrm{kız} 8$ erkek olmak üzere toplam 19 olgu ile çalışmaya başlanmıştır. Ancak 2 erkek olgu kamp sonrası takiplerine gelmediği için çalışmadan çıkarılmıştır. Kampa Türkiye'nin diğer illeri ve Diyarbakır dahil olmak üzere toplam 90 kişi katılmıştır. Diyarbakır için kamp kontenjanı 19 olması dolayısıyla olgu sayısı için güç analizi yapılamamıştır5. Kampa dahil edilme ölçütleri; olgunun 10 yaşından büyük olması, insülin enjeksiyonunun kendisinin yapması ve özbakım becerilerini yardımsız yapabilmesi olarak belirlenmiştir. Dışlama kriterleri; olgunun ve ailesinin kampa veya çalışmaya katılmak istememesi, takiplere gelmemesi ve formları eksik doldurması şeklindedir. Olguların kamp için maddi giderleri "Diyabetli Çocuklar Vakfı" tarafından karşılanmıştır.

\section{Diyabet Kampı}

Kamp 2018 yllında 29 Temmuz-7 Ağustos tarihleri arasında İznik'te gerçekleştirilen ve 6 (altı) gün devam eden bir etkinliktir. Arkadaşım Diyabet Kampı 1997 yılından itibaren İznik'te düzenli olarak yapılmaktadır. Diyabet ile ilgili temel konular (diyabet tedavisine genel yaklaşım, diyabet ile başedebilmek, karbonhidrat sayımı ve pompa kullanımı, diyabette yeni teknolojiler, evde hiperglisemi ve ketonemi yönetimi) ile ilgili eğitimler yanısıra spor (yüzme, futbol, basketbolve koşu), eğlence (mutfak atölyeleri, söyleşiler) ve sanat aktiviteleri (müzik, film saatleri) 
düzenlenmektedir. Kamp 6 gün boyunca devam eden tam yapılandırılmış bir programdan oluşmaktadır. Kampa pediatrik endokrinoloji dalında görevli 2 öğretim üyesi, 4 tane pediatrik endokrinoloji uzmanı, 3 tane pediatri uzmanı, 1 tane çocuk ve ergen ruh sağlığı uzmanı dışında diyetisyenler, diyabet hemşireleri, psikologlar, tıp, hemşirelik ve diyetisyenlik öğrencileri katılmaktadır. Ayrıca deneyimli 18 yaşın üstünde tip 1 DM tanılı daha önce kampa katılmış bireyler grup liderleri olarak kampa dahil olabilmektedir. Ekip 50 kişiden oluşmaktadır.Kamp programı, kamp sorumlusu öğretim üyeleri ve kamp danışma kurulu tarafından hazırlanmıştır.

\section{Kullanılan Ölçekler}

Çocuklar için Depresyon Ölçeği-ÇDÖ, ChildrenforDepression Inventory-CDI

Beck depresyon ölçeğinden uyarlanmıştır ${ }^{12}$. Toplam 21 sorudan oluşan formun Türkçe geçerlilik ve güvenirlik çalışması yapılmıştır'13. 6-17 yaş aralığında kullanılabilen formun kesim noktası 19 olarak belirlenmiştir.

Çocuklarda Anksiyete Tarama Ölçeği-ÇATÖ, Screenfor Child Anxiety and Related DisordersSCARED): Çocukluk çağı kaygı bozukluklarını tarama amacıyla Birmaher ve arkadaşları tarafından geliştirilen ve Türkçe geçerlik ve güvenirliği Çakmakçı tarafından yapılan Çocuklarda Anksiyete Tarama Ölçeği (ÇATÖ) ebeveyn ve çocuk formu mevcuttur. Toplam 41 maddeden oluşan ÇATÖ'de 25 ve üzeri puanın kaygı bozukluğu için uyarı niteliği taşıdığı kabul edilmektedir. Ölçek içinde ayrıca somatikpanik, yaygın anksiyete, ayrılık anksiyetesi, sosyal anksiyete ve okul fobisi alt ölçekleri bulunmaktadır ${ }^{14,15}$.

\section{Yaşam Kalitesi Ölçeği}

Çocuklar için yaşam kalitesi ölçeği-çocuk formu (8-12 yaş) ve ergenler için yaşam kalitesi ölçeğiergen formu (13-18 yaş) formu kullanılmıştır. Her iki formun Türkçe geçerlilik ve güvenirliği yapılmıştır. Ölçek puanlaması 3 alanda yapılmaktadır. Ölçek toplam puanı (ÖTP), ikinci olarak fiziksel sağlık toplam puanı (FSTP) ve duygusal, sosyal, okul işlevselliğini değerlendiren psikososyal sağlık puanı (PSTP) olarak hesaplanmaktadır.Maddeler 0-100 arasında planlamaktadır. Ölçek puanının yüksekliği sağlıkla ilgili yaşam kalitesinin iyiliği olarak algilanmaktadır ${ }^{16-19}$.

\section{HbA1c}

Glikozile hemoglobin rutinde kullanılan ortalama 3 aylık glisemik düzeyi gösteren bir belirteçtir. Ayrıca diyabetik komplikasyon gelişme riskini de öngörür ${ }^{20}$.

\section{Vücut Kitle İndeksi-VKI}

Vücut Kitle indeksi (VKİ) hem çocuklarda hem yetişkinlerde beslenme durumunu göstermede kullanılan objektif bir ölçüttür. VKİ ağırlık (kg)/ boy (m2) olarak hesaplanır ${ }^{21}$.

\section{İstatiksel Analiz}

Çalışmamızla ilgili veriler SPSS 18.0 programına kaydedildi. Daha sonra değişkenlerin normal dağılıma uyup uymadıklarına bakıldı. Değişkenlerin normal dağılım göstermeleri nedeniyle parametrik testler kullanıldı. 0 . ve 6 . Ayda ölçülen verilerin değişimini değerlendirmek için ANOVA kullanıldı. Değişimlerin birbirleri ile olan ilişkisini değerlendirmek için pearsonkorelasyon testi uygulandı. $\mathrm{p}<0.05$ anlamlı olarak kabul edildi.

\section{BULGULAR}

Çalışmaya alınan 17 olgunun 11'i kız $(\% 64,7)$, 6'sı erkek (\%35,3)'ti. Grubun yaş ortalaması 13,1(min:10-maks:17,5), tanı alma yaşı ortalaması 7,6(min:1-maks:15) olarak saptandı. Olguların yaş ortalaması 13,1(min:10maks:17,5) idi.Tanı alma yaşları 1 ile 15 yıl arasında değişmekteydi. Diyabet dışında kronik hastalığı (çölyak hastalığı) olan 2 olgu vardı. Diyabete bağlı komplikasyon (nefropati)gelişen 3 olgu mevcuttu. Nefropati düzeyi başlangıç evresindeydi ve buna bağlı ilaç kullanımı vardı. 
Demografik bulgular tablo 1'de belirtilmiștir.

Tablo 1:Sosyodemografik Özellikler

\begin{tabular}{|c|c|c|}
\hline \multicolumn{2}{|l|}{ Cinsiyet } & \\
\hline \multicolumn{2}{|l|}{$\mathrm{K} ı \mathrm{Z}$} & $\mathrm{n}=11(\% 64,7)$ \\
\hline \multicolumn{2}{|l|}{ Erkek } & $\mathrm{n}=6(\% 35 ; 3)$ \\
\hline \multicolumn{2}{|l|}{ Yaș (orttsss) } & 13,1 (min:10-maks:17,5) \\
\hline \multicolumn{2}{|l|}{ Tanı alma yaş (ort \pm ss) } & 7,6 (min:1-maks:15) \\
\hline \multirow{2}{*}{ Diyabet dışında kronik hastalık } & var & $\mathrm{n}=2(\% 11,8)$ \\
\hline & yok & $\mathrm{n}=15(\% 88,2)$ \\
\hline \multirow{2}{*}{ Diyabete bağlı komplikasyon } & var & $\mathrm{n}=3(\% 17,6)$ \\
\hline & yok & $\mathrm{n}=14(\% 82,4)$ \\
\hline
\end{tabular}

Ölçek Skorlarındaki Değişimler

Olguların HbA1c, VKİ ve ölçek skorları tabloda verilmiştir. Bu skorlara göre kamp öncesi ve kamp sonrası HbA1c, VKİ ve ölçek skoru ortalamaları arasındaki farklar istatistiksel olarak anlamlı bulunmamıştır ( $p>0,05)$.

Tablo 2:Olguların HbA1c, VKİ ölçümleri ile ölçek skorlarındaki değişimin değerlendirilmesi

\begin{tabular}{|c|c|c|c|}
\hline & Kamp öncesi & $\begin{array}{l}\text { Kamp sonrası } 6 . \\
\text { ay }\end{array}$ & $\mathrm{p}$ \\
\hline $\begin{array}{l}\text { İyi glisemik kontrol sayıs } \\
(\mathrm{HbA} 1 \mathrm{C}<8 \mathrm{mg} / \mathrm{dl})\end{array}$ & $n=3$ & $n=4$ & \\
\hline HbA1c & 9,65 (SD:2,3) & 9,83 (SD:1,7) & 0,693 \\
\hline VKİ & $\begin{array}{l}13,7 \\
(\mathrm{SD}: 2,64)\end{array}$ & 15,3 (SD:2,65) & 0,647 \\
\hline ÇDÖ & 9,4 (SD:4,9) & 9,8 (SD:6,37) & 0,759 \\
\hline ÇATÖ & $\begin{array}{ll}22,7 & \text { (SD: } \\
10,1) & \end{array}$ & 25,7 (SD:10,8) & 0,182 \\
\hline Yaşam Kalitesi Ölçeği & $\begin{array}{l}1754 \\
(\mathrm{SD}: 236)\end{array}$ & 1666 (SD:266) & 0,163 \\
\hline
\end{tabular}

Anova, $p<0,05$

(VKI: Vücut Kitle Indeksi, ÇDÖ: Çocuklar için Depresyon Ölçeği, ÇATÖ: Çocuklarda Anksiyete Tarama Ölçeği)

HbA1c Düzeyleri ve Ölçek Skorları arasındaki ilişki açısından değerlendirildiğinde başlangıçta HbA1c düzeyleri depresyon ve anksiyete skorları ile pozitif, yaşam kalitesi skorları ile negatif yönde bir ilişki bulunduğu ancak anlamlı olmadığı saptanmıştır. 6. ayda ölçülen HbA1c düzeyleri ile depresyon ve anksiyete skorları ile pozitif, yaşam kalitesi skorları ile negatif yönde bir ilişki bulunduğu ve bu ilişkinin anlamlı olduğu saptanmıştır $(\mathrm{p}<0.05)$.

Tablo 3:HbA1c düzeyleri ve ölçek skorları arasındaki ilișkinin değerlendirilmesi

\begin{tabular}{|l|l|l|c|c|}
\hline & \multicolumn{2}{|c|}{ HbA1c 0.ay } & \multicolumn{2}{c|}{ HbA1c 6.ay } \\
\hline Ölçekler & \multicolumn{1}{|c|}{$r$} & \multicolumn{1}{c|}{$\mathrm{p}$} & $\mathrm{r}$ & $\mathrm{p}$ \\
\hline ÇDÖ & 0.228 & 0.189 & 0.720 & $0.001^{*}$ \\
\hline $\begin{array}{l}\text { Yaşam kalitesi } \\
\text { Ölçeği }\end{array}$ & -0.042 & 0.437 & -0.539 & $0.013^{*}$ \\
\hline ÇATÖ & 0.374 & 0.070 & 0.544 & $0.012^{*}$ \\
\hline
\end{tabular}

r: PearsonCorrelation

$p<0.05$

(VKİ: Vücut Kitle İndeksi, ÇDÖ: Çocuklar için Depresyon Ölçeği, ÇATÖ: Çocuklarda Anksiyete Tarama Ölçeği)

\section{TARTIŞMA}

Çocuk ve ergenlerde DM; organik komplikasyonlar dişında psikiyatrik komorbiditeler açısından da risk faktörüdür7. Her ne kadar endokrin sistemi ilgilendiren bir bozukluk olarak tarif edilse de ruhsal ve sosyal boyutları olan bir rahatsızlıktır ${ }^{1}$. Ek olarak sağlıkla ilgili yaşam kalitesinde bozulma, tedavi uyum sorunları, sık hospitalizasyon, kötü glisemik kontrol çocuk ve ergenlerde gözlenmiştir7. $\mathrm{Bu}$ sorunlar göz önüne alındığında tip 1 DM tanılı çocuk ve ergenler için düzenlenen kamp etkinlikleri ortaya çıkmıştır. Kamp etkinlikleri sonrasında glisemik kontrolle ilgili sonraki ay ve ylllarda devam eden iyileşmelerle ilgili net bir kanıt yoktur ${ }^{3}$. Bizim çalışmamızda kamp sonrası 6. ayda yapılan takiplerinde HbA1c düzeyinin anlamlı düzeyde değişmediği görülmüştür. 25 olgunun alındığı ve kampın HbA1c düzeylerine etkisinin incelendiği bir çalışmada 6. ay ve 1. yılsonunda önemli düzeyde bir azalma saptanmıştır ${ }^{22}$. Bu çalışmada 7-17 yaşa aralığındaki hastalar aileler ile birlikte 7 gün süren bir kamp 
programına alınmıștır. Çalışmaya alınan olgular genel olarak bizim çalışmamızdaki gibi regülasyonu iyi olmayan olgulardı. Bizden farklı olarak düzelmenin saptanmış olması burada ailenin de katılımının sağlanmış olması olabilir. Garcia-Perez ve arkadaşlarının yapmış olduğu izlem çalışmasında kamp sonrası 1. yılda glisemik kontrolde değişiklik görülmemiştir ${ }^{23}$. $\mathrm{Bu}$ çalışma bizim çalışmamıza benzer olarak 7 gün süren 11-18 yaş aralığındaki olguların bireysel olarak alındığı bir çalışma idi. Santipraphob ve arkadaşlarının yapmış olduğu çalışmada ise 3. ayda iyileşme görülmesine rağmen, 6. aydaki takipte iyileşmenin sürdürülemediği izlenmiştir ${ }^{24}$. Her iki çalışmada diyabet ile ilgili bilgi düzeylerinin artmasına rağmen diyabet kontrolünün değişmemesi adölesan döneminin karmaşasına bağlanmıştır.

Tip 1 DM'li olgularda VKİ yüksekliği kardiyovasküler risk, insülin direnci ve diyabetin diğer komplikasyonları ile ilişkilendirilmiştir. Yaklașık 600 olgunun alındığı diyabet kampının VKİ'ne olan etkisini inceleyen bir çalışmada diyabetli olguların olmayanlara göre VKİlerinin daha fazla olduğu, kamp sonrasında diyabetli olguların VKİlerinin arttığı saptanmıştır. $\mathrm{Bu}$ artış zayıf glisemik kontrolü olan olgularda daha belirgin olarak tespit edilmiştir ${ }^{25}$. Yine kampa giden ve gitmeyen iki grubu karşılaştıran bir çalışmada kampa giden grupta VKİ değerinde anlamlı değişme görülmemiștir. Ancak gitmeyen hasta grubunda VKİ ve HbA1c düzeyinde anlamlı bir artış söz konusudur ${ }^{23}$. Bir izlem çalışmasında kampa giden olguların VKİ değerlerinin 3.ay ve 6. Ay takiplerinde artış olmasına rağmen 12 . ay VKİ değerlerinde kamp öncesi değerler ile benzer bulunmuştur ${ }^{22}$. Literatürde kampın VKI'ne etkisi ile ilgili net bir bilgi bulunmamakla beraber bizim çalışmamızda kamp sonrası 6. Ay takiplerinde VKİ değeri minimal olarak artış olsa da anlamlı düzeyde artış görülmemiştir. Bu minimal artıș tedavi uyumunun bozuk olması ile ilgili olabilir.

Tip 1 DM tanılı gençlerin tip 1 DM tanısı olmayan gençlere göre 2 kat daha fazla depresif semptoma sahip olduğu bilinmektedir ${ }^{5}$. Depresyon kadar anksiyete belirtileri de bu çocuk ve ergenlerde yaygındır. Tip 1 DM'li olguların \%13 ile \%23'ü yaşamlarının bir bölümünde anksiyete belirtileri göstermiştir9 . Kamp sonrası anksiyete düzeylerinin değerlendirildiği bir izlem çalışmasında kamp sonrası anksiyete düzeylerinin değişmediği görülmüștür ${ }^{23}$. Kampa katılan ve katılmayan tip 1 DM'li olguların anksiyete düzeylerini inceleyen bir çalışmada izlemde kampa katılan olguların anksiyete düzeylerinde azalma olduğu saptanmıştır. Kampa katılmayan olgularla karşılaştırıldığında bu değişimin anlamlı olmadığı bulunmuştur ${ }^{26}$.Ülkemizde yapılan bir çalışmada diyabet kampına katılan 10-17 yaş aralığındaki olguların kamp öncesi ve kamp bitişi depresyon ve kaygı düzeyleri incelenmiştir. İlk ve son testler arasında anlamlı düzeyde bir fark bulunmamıştır ${ }^{1}$. Wang ve arkadaşlarının yapmış olduğu bir çalışmada kampa katılan ve katılmayan tip 1 diyabetli hastalar değerlendirilmiştir. Ebeveyn değerlendirmelerinin sonucuna göre kamp sonrası anlamlı bir değişiklik olmadığı, literatürle uyumlu olarak kız olgularda psikiyatrik komorbiditenin, özellikle depresyon skorlarının daha fazla olduğu saptanmıștır ${ }^{27}$. Diyabet kamplarının yaşam kalitesi üzerine etkisi değerlendirildiğinde genel olarak olumlu sonuçlara varılmıștır ${ }^{23,27}$. Ancak bazı çalışmalarda bu olumlu sonuçlar gösterilememiştir.Diyabet kampına en az bir kere katılmış olan olgularla hiç katılmamış olan olguları karşılaştıran bir çalışmada kampın yaşam kalitesine pozitif bir etkisi olmadığı gösterilmiştir ${ }^{28}$. Yaşam kalitesi değişimlerinin yaş, cinsiyet, sosyokültürel ve sosyoekonomik faktörlerden bağımsız değerlendirilemeyeceği bu nedenle çok boyutlu bir yapısı olduğu için 
net sonuçlar elde edilemeyeceği savunulmaktadır ${ }^{29}$.Bizim çalışmamızda depresyon, anksiyete ve yaşam kalitesi düzeylerinin kamp sonrası anlamlı düzeyde değişmediği görülmüştür. Ölçeklerin kesim noktası açısından bakıldığında ölçeklerin ortalamalarının herhangi bir psikopatolojiyi düşündürecek düzeyde olmadığı belirlenmiștir.

Çalışmamızda 6. Ayda ölçülen HbA1c düzeyleri ile depresyonarasında pozitif bir ilişki saptanmıştır. Bu bulgu literatür ile uyumlu bulunmuştur. Adölesanlar ve genç erişkinlerin alındığıbir çalışmada depresif bulguların kötü glisemik kontrolle ilişkili olduğu gösterilmiştir ${ }^{9}$. Tip 1 DM tanılı çocuk ve ergenlerde yapılan, depresyon ve depresyon belirleyicilerinin değerlendirildiği bir çalışmada HbA1c yüksekliğinin depresyon için tek önemli belirleyici olduğu saptanmıştır. Ayrıca bizim gibi gelişmekte olan ülkelerde tip $1 \mathrm{DM}$ ve depresyon birlikteliği sıklığının fazla olduğu gösterilmiştir ${ }^{30}$. Bir metaanalizde $\mathrm{HbA1c}$ ve depresyon arasında pozitif korelasyon saptanmıştır ${ }^{31}$. $\mathrm{Bu}$ araştırmaların sonuçları bizim çalışmamızı destekler niteliktedir.

Aynı şekilde anksiyete belirtileri de düşük yaşam kalitesi, zayıf yönetim ve kötü glisemik kontrol ile ilişskilidir6 ${ }^{\text {. }} 14$ çalışmanın tarandığı bir metaanalizdeanksiyeteninglisemik kontrol üzerine olumsuz etkileri saptanmıștır ${ }^{31}$.Kore'de yapılan ve diyabet kampına katılan olguların değerlendirildiği bir çalışmada yüksek HbA1c düzeyleri ve düşük yaşam kalitesi ile ilişkili bulunmuştur ${ }^{32}$. Diyabet kampına katılan 98 olgunun değerlendirildiği bir çalışmada HbA1c düzeyleri yüksek olanlarda yaşam kalitesi puanları düşük, anksiyete skorları yüksek olarak bulunmuştur ${ }^{3}$.Kamp sonrası bir yıl boyunca izlenen olguların katıldığı bir çalışmada HbA1c ile yaşam kalitesi arasında tutarlı bir ilişki saptanmamıştır ${ }^{24}$. Bizim çalışmamızda HbA1c ve anksiyete arasında pozitif bir ilişki, yaşam kalitesi ile negatif yönde bir ilişki saptanmıştır.
Araştırma örnekleminin sayıca az olması, izlemin 6 ay ile sınırlı kalması çalışmamızın kısıtlılıklarındandır.Bundan sonra yapılacak çalışmalar için bir ön çalışma sayılabilir. $\mathrm{Bu}$ alanda yapılacak büyük örneklemli ve daha uzun izlem çalışmalarına ihtiyaç duyulmaktadır. Kamp etkilerinin uzun dönem sonuçlarını inceleyen çalışmalar literatürde mevcut değildir.

Sonuç olarak anektodal ve kalitatif kanıtlara göre diyabet kampları çocuk ve gençlerin deneyimlerini paylaştığl, akran desteği gördügüu, toplumdan kendisini daha az izole hissettiği eğlenceli yerlerdir. Ancak kampların olguların üzerindeki psikiyatrik etkileri net olarak açık değildir. Kamplarda yapılandırılmış psikiyatrik tedavilerin uygulanmayışı (bilişsel davranışçı terapi, kabul kararlılık terapisi gibi) bu negatif sonuçlarla ilişkili olabilir. Bizim çalışmamı kamp etkinliğinin depresyon, anksiyete ve yaşam kalitesi üzerine kısa dönemde olumlu bir etkisi olmadığını ortaya koymuştur.

Sunulduğu kongre: 2-5 Mayıs 2019 Ulusal Çocuk ve Ergen Ruh Sağlığı ve Hastalıkları Kongresi'nde poster olarak sunulmuştur.

Etik Kurul Kararı: Çalışmaya başlamadan önce SBÜ Gazi Yaşargil Eğitim ve Araştırma Hastanesi Klinik Araştırmalar Etik Kurulundan çalışma izni alınmıştır. (19.04.2019 tarihli ve 259 sayılı karar).

Çıkar Çatışması Beyanı: Yazarlar çıkar çatışması olmadığını bildirmişlerdir.

Finansal Destek: Bu çalışma her hangi bir fon tarafından desteklenmemiştir.

Declaration of ConflictingInterests:The authors declare that they have no conflict ofinterest.

Financial Disclosure: No financial support was received. 


\section{KAYNAKLAR}

1. Bahali MK, Tahiroğlu AY, Firat S, et al. Bir diyabet kampı etkinliği. Anadolu Psikiyatri Dergisi 2006; 7: 218-22.

2. World HealthOrganization. What are the risks of diabetes in children? 2011. Retrieved from http://www.who.int/features/qa/65/en/inde x.html.

3. Fegan-Bohm K, Weissberg-Benchell J, DeSalvo D, et al. Camp for Youth With Type 1 Diabetes. Curr Diab Rep 2016; 16: 68.

4. American Diabetes Association. Diabetes management at camps for children with diabetes. Diabetes Care 2012; 35: 72-5.

5.http://www.arkadasimdiyabet.com\%2Fkam pzamani\%2Fkampzamani\&usg=AOvVaw3SlZid Y5z8wgb-FL8IsLYW.

6. Herzer M, Hood KK. Anxiety symptoms in adolescents with type 1 diabetes: association with blood glucose monitoring and glycemic control. J Pediatr Psychol 2010; 35: 415-25.

7. Dybdal D, TolstrupJS, Sildorf SM, Boisen KA, et al. Increasing risk of psychiatric morbidity after childhood onset type 1 diabetes: a populationbased cohort study. Diabetologia 2018; 61: 8318. doi: 10.1007/s00125-017-4517-7.

8. McGrady ME, Laffel L, DrotarD, et all. Depressive symptoms and glycemic control in adolescents with type 1 diabetes: mediational role of blood glucose monitoring. DiabetesCare 2009; 32: 804-6.

9. Bernstein CM, Stockwell MS, GallagherMP,et al.Mental health issues in adolescents and young adults with type 1 diabetes: prevalence and impact on glycemic control. Clin Pediatr (Phila) 2013; 52: 10-15.

10. Nielsen HB, Ovesen LL, Mortensen LH, et al. Type 1 diabetes, quality of life, occupational status and education level - A comparative population-based study. Diabetes Res Clin Pract 2016; 121: 62-8.
11. Matziou V, Tsoumakas $\mathrm{K}$, Vlahioti E, et al. Factorsinfluencingthequality of life of youngpatientswithdiabetes. Journal of Diabetes 2011; 3: 82-90. doi: 10.1111/ j.17530407.2010.00106.x.

12. Kovacs M. Rating scale to assess depression in school aged children. Acta Paedo psychiat 1981; 46: 305-15.

13. Öykü B. Çocukla rİçin Depresyon Ölçeği: Geçerlik ve güvenirlik çalışması. Türk Psikiyatri Dergisi 1991; 2: 132-6.

14. Birmaher B, Brent DA, Chiappetta L, et al. Psychometric properties of the screen for Child Anxiety Related Emotional Disorders (SCARED): A replicationstudy. J AmAcad Child AdolescPsychiatry 1999; 38: 1230-6.

15. Çakmakçı FK. Çocuklarda anksiyete bozukluklarını tarama ölçeği geçerlik ve güvenirlik çalışması. Çocuk ve Gençlik Ruh Sağlığı Dergisi 2004; 11: 2.

16. Varni JW, Seid M, Rode CA. The PedsQL: measurement model for the Pediatric Quality of Life Inventory. MedCare 1999; 37: 126-39.

17. Varni JW, Seid M, Kurtin PS. ThePedsQLTM 4.0 : reliability and validity of thePediatric Quality of life İnventory Version TM version 4.0 generic corescales in healthy and patient populations. Med Care 2001; 39: 800-12.

18. Çakın Memik N. Çocuklar için yaşam kalitesi ölçeği geçerlik ve güvenilirlik çalışması. Yayınlanmamış uzmanlık tezi, 2005. Kocaeli Üniversitesi Tıp Fakültesi.

19. Çakın Memik N, Ağaoğlu B, Coşkun A, et al. Çocuklar için yaşam kalitesi ölçeğinin 13-18 yaş ergen formunun geçerlik ve güvenilirliği. Türk Psikiyatri Dergisi 2007; 18: 353-63.

20. Schnell O, Crocker JB,Weng J. Impact of HbA1c Testing at Point of Care on Diabetes Management. Journal of Diabetes Science and Technology 2016; 11: 611-7. doi:10.1177/1932296816678263. 
21. Physical status: The use and interpretation of anthropometry. Report of WHO Expert Commitee. WHO Technical Report Series 854. Geneva: World HealthOrganisation, 1995.

22. Karagüzel G, Bircan I, Erişir S, et al. Metabolic control and educational status in children with type 1 diabetes: effects of a summer camp and intensive insulin treatment. ActaDiabetol 2005; 42: 156-61.

23. García-Pérez L, Perestelo-Pérez L, SerranoAguilar $\mathrm{P}$, et al. Effectiveness of a psychoeducative intervention in a summer camp for children with type 1 diabetes mellitus. Diabetes Educ 2010; 36: 3-7.

24. Santiprabhob J, Kiattisakthavee P, Likitmaskul S, et al. Glycemic control, quality of life and self-care behavior among adolescents with type 1 diabetes who attended a diabetes camp. Southeast Asian J Trop Med Public Health 2012; 43: 172-84.

25. Oden JD, Franklin B, Fernandez E, et al. Effects of residential summer camp on body mass index and body composition in type 1 diabetes. Pediatr Diabetes 2018; 19: 782-7. doi: 10.1111/pedi.12649.

26. McCraw RK,Travis LB. Psychological Effects of a Special SummerCamp on Juvenile Diabetics. Diabetes, 1973; 22: 275-278. doi:10.2337/diab.22.4.275.
27. Wang YC, Stewart S, Tuli E, et al. Improved glycemic control in adolescents with type 1 diabetes mellitus who attend diabetes camp. Pediatr Diabetes 2008; 9: 29-34.

28. Cheung R, YoungCureton V, Canham DL. Quality of life in adolescents with type 1 diabetes who participate in diabetes camp. J SchNurs 2006; 22: 53-8.

29. Tumini S, Anzellotti MT, Chiarelli F. Camps for children with T1 DM. Acta Biomed 2003; 74 Suppl 1: 32-4.

30. Khater D, Omar M. Frequency and risk factors of depression in type 1 diabetes in a developing country. J Pediatr Endocrinol Metab 2017; 28; 30: 917-922. doi: 10.1515/jpem2016-0414.

31. Buchberger B, Huppertz H, Krabbe L, et al.Symptoms of depression and anxiety in youth with type 1 diabetes: A systematic review and meta-analysis. Psychoneuroendocrinology 2016; 70: 70-84. doi: 10.1016/j.psyneuen.2016.04.019.

32. Boo S, Ahn Y, Lee JE,et al. DiabetesSpecificQuality of Life of Korean Children and Adolescents With Type 1 Diabetes. International Journal of Nursing Knowledge 2015; 27: 62-9. doi:10.1111/20473095.12075.

33. Li R, Xiong F, Hu Y, et al. Survey on quality of life in children and adolescents with type 1 diabetes. Zhejiang Da XueXueBaoYiXue Ban. 2013; 42: 388-95. 